\title{
流動している液体中の短繊維の運動
}

\author{
中 村 克 孝*, 美 馬源 次 郎** \\ (1975 年 12 月 2 日受付)
}

\section{The Motion of the Staples in Moving Liquid}

\author{
K. NAKAMURA* and G. Mima**
}

(Received December 2, 1975)

\begin{abstract}
The method of alignment of staples, such as whiskers, is one of the important processes used to make fiber reinforced composite materials. The fluid mechanical and the utilizing plastic flow methods have been devised for the purpose. As for the fluid mechanical method, a novel method was developed by Calow, C.A. and Wakelin, R.J. However, they didn't mention on the viscous effect of working liquid, which is a character of importance, on the alignment of staples. Moreover, there are a few mistaken parts in their theoretical analyses. In theoretical analyses, we considered the viscous effect of the working liquid on the alignment of staples. And using the experimental apparatus which consists of a tank and a rectangular duct, we researched the effects of the length of a duct, the aspect ratio of staples and the velocity and viscosity of the working liquid on the alignment of staples.
\end{abstract}

\section{1. まえがき}

繊維強化複合材料の作成法の一つに, ウィスカーなど の短瀻維の配列化の方法があり，それには流体工学的方 法1や，塑性流動を利用した方法2)が考兄られている. ところが短繊維の配列に関する研究は非常に少ないのが 実情である.

流体工学的方法に関しては, Calow と Wakelin ${ }^{1)} の$ すぐれた研究が見られる.彼らの方法は，ウィスカーを 破損させないで，かつ母材中に一方向にウィスカーを配 列させるために, ゾル状でテープを作り，第二段階でテー プを压縮して纎維強化金属材料を作るといら巧妙な方法 である.ところが，作動液の重要な性質である粘度が， 短瀻維の配列におよぼす影響については触れられていな い.さらに彼らの理論解析には, 流体工学的見地から検 討するといくつかの欠陷が見られる．それらは，短瀻維 の回転による相対速度, レイノルズ数と抗力係数の取扱 いなどである.

\footnotetext{
$*, * *$ 阿南工業高等専門学校 (774阿南市見能林町青木) Anan Technical College, Anan 774, Japan

* 助手 Assistant, ${ }^{* *}$ 校長 The President
}

著者らは, 短瀻維の流体工学的配列に関して, 理論と 実験の両面から検討することを目的としている.

すなわち第一段階として, 流動している液体中の短絨 維の運動におよぼす作動液の粘度を考慮した運動方程式 を導いた. 次に運動方程式の数值計算により, 速度こう 配, 短緘維の長さと直径, 流体の密度と粘度, 短繊維の 密度の影響を定量的に見いだした。同時に，短瀻維の配 列におよぼすこれら諸因子ならびに管路の長さと流速の 影響を，タンクと管路とからなる装置を用いて実験的に 調べた。実験には観察を容易にするため, 短繊維として 人間の頭髮を使用した.

その結果, 短瀻維はタンク内で一方向に配列を完了す ることがわかった。それゆえ，管路壁とのまさつによる 悪影響を避けるには，管路の長さは短い汪どよい。さら に粘度の増大，流速の増大につれ，管路内での短繊維の 配列は良好となることがわかった。

$$
\begin{aligned}
& a: \text { 速度こう配 } \\
& \mathrm{A} \cdot \mathrm{R} . \equiv 2 l / d: \text { アスペクト比 } \\
& A_{\mathrm{s}}: \text { 管路断面積 } \\
& A_{\mathrm{t}}: \text { タンク内での代表面積 }
\end{aligned}
$$




\footnotetext{
$C_{\mathrm{D}}$ : 抗力係数

$D:$ 管路の厚さ（短辺の長さ）

$d:$ 短繊維の直径

$F:$ 抗力

$H:$ タンク内の液位

$h \equiv l d /(7.4 \cdot \mu / \rho)$

$I:$ 短繊維の慣性モーメント

$J \equiv 16 \mu /\left(P d^{2}\right)$

$L$ : 管路の長さ

$l:$ 短緎維の長さの 2 分の 1

$P:$ 短繊維の密度
}

$\operatorname{Re} \equiv\left|U_{r \text { el }}\right| \cdot d /(\mu / \rho):$ 短瀻維に関するレイノルズ数

$\operatorname{Re}_{l}: r=l$ に打ける $\operatorname{Re}$

$\operatorname{Re}_{\mathrm{s}} \equiv v_{\mathrm{s}} \cdot 4 r_{\mathrm{h}} /(\mu / \rho)$ : 管路に関するレイノルズ数

$r:$ 短緎維の重心からの距離

$r_{\mathrm{h}}:$ 水力半径

$t$ : 時間

$U:$ 短繊維の重心の速度

$U_{r \text { el }}: r$ の位置での相対速度

$V:$ 流体の速度

$v_{\mathrm{s}}:$ 管路内の流体の平均速度

$v_{\mathrm{t}}:$ タンク内の流体速度

$v_{\mathrm{tm}}: v_{\mathrm{t}}$ の平均值

$v_{\mathrm{t} \text { max }}: v_{\mathrm{t}}$ の最大值

$W:$ 管路の幅

$x$ : 管路の軸方向距離

$y \equiv r \sin \theta$

$\theta:$ 短緎維の傾き角度

$\dot{\theta}:$ 角速度

$\ddot{\theta}:$ 角加速度

$\lambda:$ 管まさつ係数

$\mu:$ 流体の粘性係数

$\nu \equiv \mu / \rho$ : 流体の動粘性係数

$\pi:$ 円周率

$\rho:$ 流体の密度

\section{2. 理論}

\section{1 運動方程式}

Fig. 1 に示した速度こう配を有する流体中に角度 $\theta$ だけ傾けて置かれた直径 $d$, 長さ $2 l$ の円柱を考える. 点Oで円柱と流体とのあいだのすべりを無視する.

円柱に直角な方向の速度は, 図において右上からの流 れを正と定めると の位置で次のようになる.

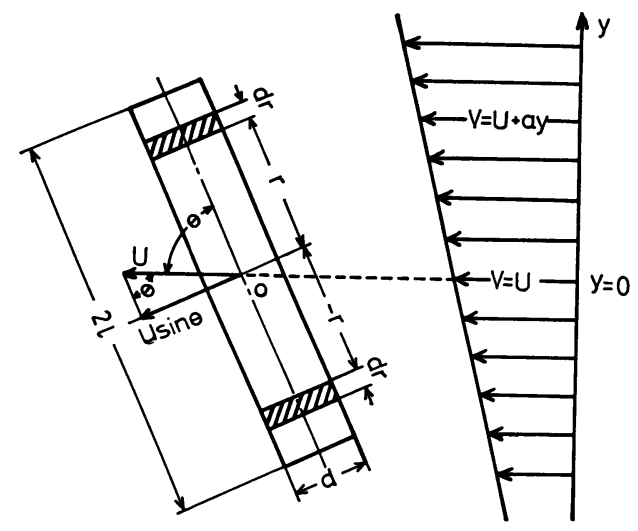

Fig. 1 Cylinder in shear flow.

流体の速度 : $(U+\operatorname{ar} \sin \theta) \sin \theta$

円柱の速度 : $U \sin \theta-r \dot{\theta}$

円柱の相対速度 : $U_{r \text { el }}=r\left(\dot{\theta}+a \sin ^{2} \theta\right)$

円柱の重心 $\mathrm{O}$ から距離 $\boldsymbol{r}$ だけ離れた長さ $d r$ の円柱要 素を考える. この小さな要素に働く力 $d F$ は, 抗力係数 $C_{D}$ を用いると

$$
d F \equiv \frac{C_{D}}{2} \rho\left(U_{r \mathrm{el}}\right)^{2} \cdot d \cdot d r
$$

$C_{D}$ は円柱に関するレイノルズ数 $\mathrm{Re}$ が $\mathrm{Re}<7.4$ のと き, Oseen ${ }^{3)}$ の式

$$
C_{D}=F /\left(\frac{1}{2} \rho U_{r \mathrm{el}^{2}}{ }^{2} \cdot d \cdot 2 l\right)=\frac{8 \pi}{\operatorname{Re} \ln (7.4 / \mathrm{Re})}
$$

が成立する．式(3)および式(1)を式(2)に代入すると

$$
\begin{aligned}
d F & =\frac{8 \pi \rho\left(U_{r \mathrm{el}}\right)^{2}}{2 \operatorname{Re} \ln (7.4 / \mathrm{Re})} d \cdot d r \\
& =\frac{-4 \pi \mu r\left(\dot{\theta}+a \sin ^{2} \theta\right) \cdot d r}{\ln r+\ln \left\{\left|\dot{\theta}+a \sin ^{2} \theta\right| \cdot d /(7.4 \mu / \rho)\right\}}
\end{aligned}
$$

が得られる.ここで

$$
\operatorname{Re} \equiv\left|U_{r \text { el }}\right| \cdot d /(\mu / \rho)
$$

である。

いっぽう全円柱に働くトルクは

$$
I \ddot{\theta}=-\int_{-l}^{l} d F \cdot r=-2 \int_{0}^{l} d F \cdot r
$$

となる. 式(4)を代入すると 


$$
\begin{aligned}
& I \ddot{\theta}=8 \pi \mu\left(\dot{\theta}+a \sin ^{2} \theta\right) \\
& \times \int_{0}^{l} \frac{r^{2} d r}{\ln r+\ln \left\{\mid\left(\dot{\theta}+a \sin ^{2} \theta \mid \cdot d /(7.4 \mu / \rho)\right\}\right.}
\end{aligned}
$$

が得られる。式(7)の右辺に含まれる積分は, $b \equiv\left|\dot{\theta}+a \sin ^{2} \theta\right| \cdot d /\{7.4 \mu / \rho\}$ とおけば

$$
\begin{aligned}
\int_{0}^{l} \frac{r^{2}}{\ln b r} d r & =\left(\int_{0}^{l} r^{2} d r\right)\left\lceil\frac{1}{\ln b r}\right]_{0}^{l}-\int_{0}^{l}\left\{\int r^{2} d r\right\} \\
& \times \frac{d\left\{\frac{1}{\ln b r}\right\}}{d r} d r=\frac{l^{3}}{3 \ln b l} \\
& \times\left\{1+\frac{1}{3 \ln b l}+\frac{2}{9(\ln b l)^{2}}+\cdots\right\}
\end{aligned}
$$

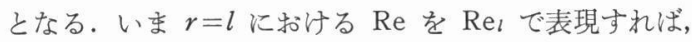
$\ln b l<-1$ のとき $b l \equiv \operatorname{Re}_{l} / 7.4<0.368$ ，いいかえると $\mathrm{Re}_{l}<2.72$ のとき式(8)の第 2 項以下を略して近似すれば

$$
\begin{aligned}
I \ddot{\theta} & =8 \pi \mu\left(\dot{\theta}+a \sin ^{2} \theta\right) \\
& \times \frac{l^{3}}{3 \ln \left\{\left|\dot{\theta}+a \sin ^{2} \theta\right| \cdot l d /(7.4 \mu / \rho)\right\}}
\end{aligned}
$$

となる、

円柱の慣性モーメント

$$
I=P^{\prime}\left(\frac{\pi d^{4} l}{2}\right)\left\{\frac{1}{16}+\frac{1}{12}(\text { A.R. })^{2}\right\}
$$

は, A.R. 三2l/d》1のとき次式で近似される.

$$
I=P \cdot \pi d^{4} l(\text { A.R. })^{2} / 24
$$

式(10)を式(9)に代入して整理すると，式(11)で示される運動 方程式を得る。

$$
\begin{aligned}
\ddot{\theta} & =\frac{16 \mu\left(\dot{\theta}+a \sin ^{2} \theta\right)}{P d^{2} \ln \left\{\left|\dot{\theta}+a \sin ^{2} \theta\right| \cdot l d /(7.4 \mu / \rho)\right\}} \\
& =\frac{J\left(\dot{\theta}+a \sin ^{2} \theta\right)}{\ln h+\ln \left\{\left|\dot{\theta}+a \sin ^{2} \theta\right|\right\}}
\end{aligned}
$$

ここで

$$
\left.\begin{array}{l}
J \equiv 16 \mu /\left(P d^{2}\right) \\
h \equiv l d /(7.4 \mu / \rho)
\end{array}\right\}
$$

と定義する。

\section{2 式(11)の数値計算に用いた条件}

1）速度こう配 $a$ の仮定

Calow と Wakelin ${ }^{12}$ が用いた仮定と同様,断面積比 $A_{\mathrm{t}}$ / $A_{\mathrm{s}}=256$, 管路内の速度 $v_{\mathrm{s}}=2.54 \mathrm{~cm} / \mathrm{s}$ とすれば, 連続

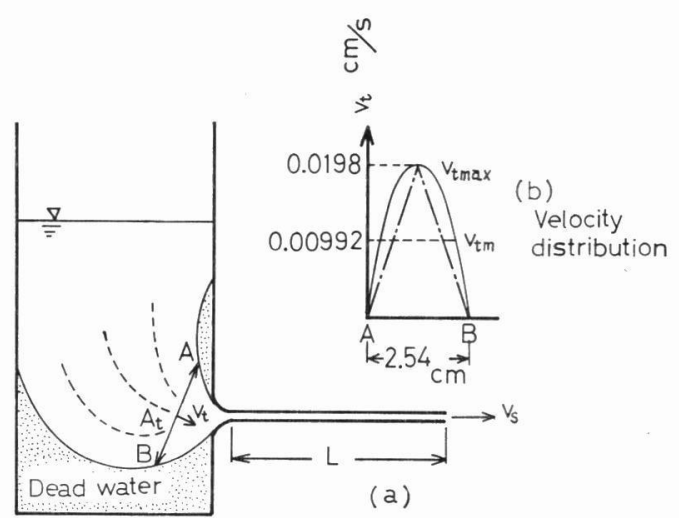

Fig. 2 Assumptions for the determination of the velocity gradient.

の式より, タンク内の断面 $\mathrm{AB}$ における平均速度は $v_{\mathrm{tm}}$ $=0.00992 \mathrm{~cm} / \mathrm{s}$ となる. 断面積が $A_{\mathrm{t}}$ である断面 $\mathrm{AB}$ の直径を $2.54 \mathrm{~cm}$ とすれば, 層流のときは, HagenPoiseuille の式より Fig. 2 (b) に示す放物線の速度分布 となる、そのとさ，最大速度 $v_{\mathrm{t}} \max =2 v_{\mathrm{tm}}$ である。速 度こう配は, 断面 $\mathrm{AB}$ の中からの距離によって異なる が，図に示した一点鎖線で近似して代表させると $a=$ $0.01561 / \mathrm{s}$ が得られる.

\section{2) $J$ そ $h$}

著者らが行なった実験条件， $\nu=(13.0 \sim 108) \times 10^{-6}$ $\mathrm{m}^{2} / \mathrm{s}, \quad d=(80 \sim 120) \mu, 2 l=(1.5 \sim 5) \mathrm{mm}$ (Fig. 5 参照) のとき, 近似的に $J=10^{5} \mathrm{1} / \mathrm{s}, \ln h=(-9 \sim-8)$ となる. 計算の際には， $a, J, h$ のオーダを変化させて，これら 因子の影響を見いだす。

\section{3 式 (11)の計算結果}

Runge-Kutta 法により式 (11) を数值計算した結果の代 表例を Fig. 3 に示寸. 時間 $t=0$ のとき, 傾き角度 $\theta=\pi / 2$ であった短繊維（円柱と仮定している）が回転し て, $\theta=0$ となるに要する時間を配列時間と呼ぶことに する。

これらの曲線より, 速度こら配 $a$ の増大, $J$ の増大なら びに $h$ の増大 ( $\ln h$ の増大) につれて, 短繊維の配列時 間は減少することがわかる. いいか光ると, 速度こう配, 短繊維の長さ, 流体密度㧍よび流体の粘性係数の増大に つれて配列時間は減少する。そして, 短䋐維の直径, 短 繊維の密度の減少によっても, 配列時間は減少する。こ こで $\mu, d$ は，それぞれ $J, h$ の両者に含まれるが，配 列時間に扣よぼす $\mu, d$ の個々の影響は, 同様な計算に より確認された。 


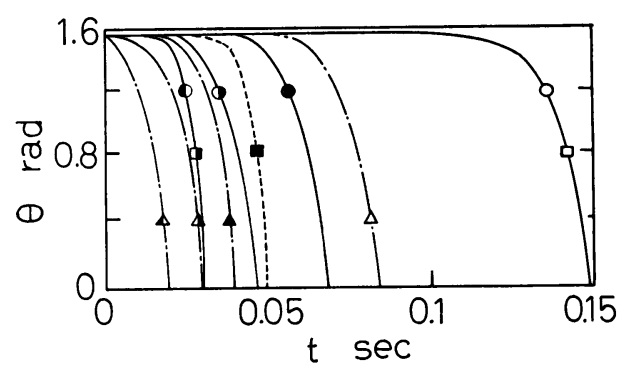

Fig. 3 Alignment time.

$J=4000 \mathrm{l} / \mathrm{s}, \ln h=-10.4(\circ a=0.0156 \mathrm{l} / \mathrm{s}$, - $a=0.05 \mathrm{l} / \mathrm{s}, \bigcirc a=0.156 \mathrm{l} / \mathrm{s}, \bigcirc a=0.53 \mathrm{l} / \mathrm{s})$ - - $a=0.015 \mathrm{l} / \mathrm{s}, \ln h=-10.4$ ( $\square J=4000 \mathrm{l} / \mathrm{s}$, - $J=5000 \mathrm{l} / \mathrm{s}, \square J=6800 \mathrm{l} / \mathrm{s}$ )

$-\cdots a=0.156 \mathrm{l} / \mathrm{s}, J=6800 \mathrm{l} / \mathrm{s}(\triangle \ln h=-20.8$,

$\Delta \ln h=-15.6, \Delta \ln h=-12.0, \Delta \ln h=-10.4)$

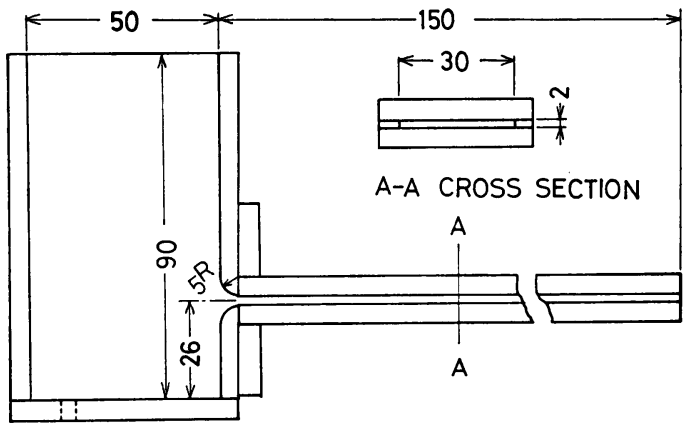

Fig. 4 Experimental apparatus.

\section{3. 実験装置と実験方法}

不規則な方向に置かれた短緎維の一方向への配列が, はたして理論が示すよらにタンク内で短時間に完了する のか，それとも管路が配列に重要な作用をおよぽすかど らかを見いだすため，以下に示す実験を行なった。

Fig. 4 に示すように, タンクと管路から配列装置が成 り立っている．タンク内および管路内の流動と短繊維の 配列状態が, 外部から観察できるように, 両者は透明塩 化ビニール板で作られている. 矩形管路の短辺は目盛付 きの物差しを用いてあるので，軸方向位置が容易に見い だせる. 入ロノズルは, 四辺とも半径 $5 \mathrm{~mm}$ の四分円 に作られている.タンク背面には流れの可視化用のトレ 一サ注入口が設けられている．管路には王力降下測定用 の静圧孔が設けられ，マノメータに接続されている。

タンク内の液面の降下速度は, 写真撮影による方法,

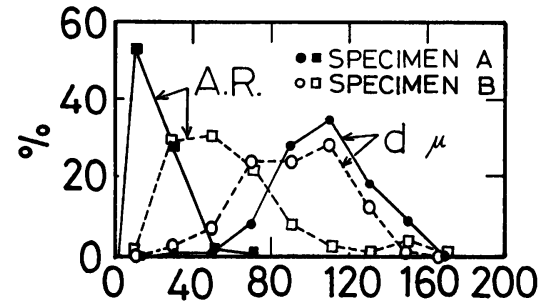

Fig. 5 Dimensions of specimens.

ならびに液面が一定距離を降下するに要する時間を手動 でパルス化して電磁オシログラフに記録する方法の両者 で求めた.

タンク内の流跡線 と流速分布は，タンクへの注水時 に, 自然に液中に生ずる微小気泡の写真撮影から求めら れた，写真撮影の際には，平面鏡を用いて正面および上 面からの同時撮影が可能となっている.

作動流体として, 水道水ならびに各種濃度のグリセリ ン水溶液を用いて粘度の影響を調べた，粘度測定は，恒 温水槽内に静置されたオストワルド粘度計を用いて行な われた。

短緎維として観察を容易にするため人間の頭髪を用い た. 資料 $\mathrm{A} ， \mathrm{~B}$ はそれぞれ 62 本，72 本について長さ， 直径, アスペクト比が工具顕微鏡で測定された (Fig. 5).

頭髪の配列評価はすべて写真から求められた．管路内 では，管路入口からの距離が $10 \mathrm{~mm}$ と $30 \mathrm{~mm}$ のあい だおよび $90 \mathrm{~mm}$ と $110 \mathrm{~mm}$ のあいだの 2 カ所で，そ れぞれ軸方向との偏角 $\theta$ の分布を求めることにより配列 状態を評価した

\section{4. 実験結果とその考察}

\section{1 タンク内の流れ}

タンクヘの注水時に自然にグリセリン水溶液中に生ず る微小気泡の写真撮影から, 流跡線と速度分布を求めた. 流跡線を求めるには，代表例を示した Fig. 6 (a) のよ らに, カメラの露出時間の長いものが適切である.これ らの写真より, Calow と Wakelin ${ }^{1)}$ が指摘したように, タンク底部と入ロノズル上方に死水域が認められた。

入口ノズル付近では流速が増大するので，露出時間を 短くし (Fig. 6 (b)), 気泡の軌跡の長さと路出時間より 速度分布を求めた。 得られた結果を Fig. 7 (a) に示す.

Fig. 7 (a) より, 入口ノズルの影響の少ないタンク上 方の流れは, 矩形管内の層流速度分布 ${ }^{4)}$ とよい一致を示 す. 動粘性係数 レが $49.7 \times 10^{-6} \mathrm{~m}^{2} / \mathrm{s}$ の場合の流跡線は, 


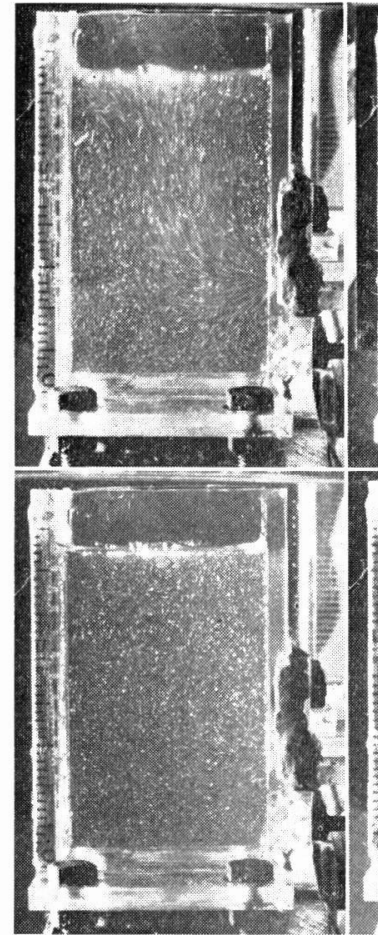

(1)

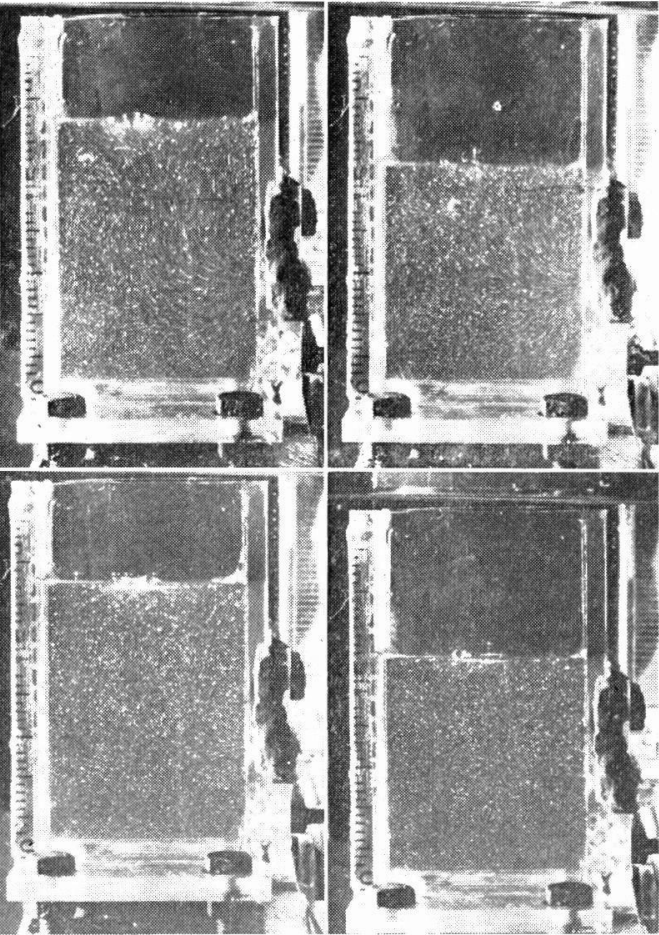

(2) (a)

(b)

Fig. 6 Flow in the tank.

(1) $H=50 \mathrm{~mm}, v_{\mathrm{s}}=1.01 \mathrm{~cm} / \mathrm{s}$, (2) $H=40 \mathrm{~mm}, v_{\mathrm{s}}=0.801 \mathrm{~cm} / \mathrm{s}, \quad$ (3) $H=30 \mathrm{~mm}, v_{\mathrm{s}}=0.596 \mathrm{~cm} / \mathrm{s}$, (a) Exposure $5 \mathrm{sec}$, (b) Exposure $1 \mathrm{sec}, \quad v=108 \times 10^{-6} \mathrm{~m}^{2} / \mathrm{s}$.

Fig. 7 (a) に示した $\nu=108 \times 10^{-6} \mathrm{~m}^{2} / \mathrm{s}$ のとさとほとん ど相違がなかった。

速度測定におよ淁す気泡の浮力の影響は, Stokes の 抵抗の式 ${ }^{5)}$ 用いて評価される.Fig. 7 (a) に示した横 方向 ( $x$ 方向) の速度分布は浮力の影響を受けないこと は自明である、いっぽう高さ力向 ( $H$ 方向) には浮力の 影響が考克られるが，気泡径が $0.1 \mathrm{~mm}$ 以下では， $H=$ $50 \mathrm{~mm}$ 付近の流体の最大速度には打拈きな誤差は生じ ない，ただし，死水域付近では，浮力にもとづく影響が 無視できない。

\section{2 管路内の流れ}

管路は矩形管であるので，層流の速度分布は，タンク 内と同様 Boussinesq の式4) から求められるが，測定は 非常に困難である.

管路内の層流の管季さつ損失も Boussinesq の式から 計算される. 著者らが用いた矩形管路の断面は, 長辺と 短辺の比が $W / D=15$ であり, この比が大きい場合は計 算の容易な近似式6)でる厳密解とよく一致する。
著者らが用いた管路は十分長いので，タンク内の管ま さつ損失，入口損失ならびに出口損失は，管路の管まさ つ損失に比して十分小さいと考光られる。この仮定を用 いてタンク内の水頭と流下速度の測定值から管まさつ損 失を求めたところ Fig. 8 に示す結果が得られた.

図上り，実験值は層流の理論式 4

$$
\lambda=1.38 \times 64 / \mathrm{Re}_{\mathrm{s}} \text { ただし } W / D=15
$$

に汴一致することがわかる。図には $W / D=1$ および $W / D=\infty$, ならびに円管の場合に和汀る理論值が参考と して記されている.ここで, 管路に関するレイノルズ数 $\operatorname{Re}_{\mathrm{s}} \equiv v_{\mathrm{S}} \cdot 4 r_{\mathrm{h}} / \nu$, 水力半径 $r_{\mathrm{h}}=D \cdot W / 2(D+W)$ である.

\section{3 タンク内での短繊維の配列}

資料 Bのタンク内での配列状態を写真撮影したものの 一例を Fig. 9 に示す.

タンク内の作動液が流下しはじめると同時に, 入口, ズル付近で配列をはじめ, 資料の長手方向の軸は流跡線 と一致する. Fig. 9 (a) の写真を模式化して Fig. 7 (b) 
-..- Theoretical velocity

- Experimental values

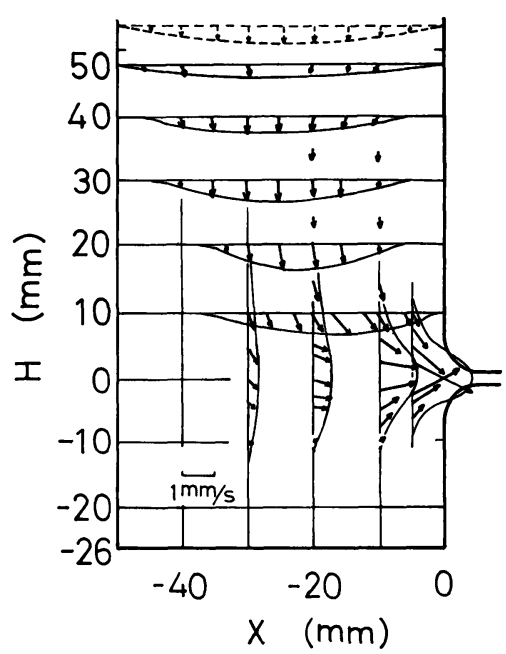

(a)

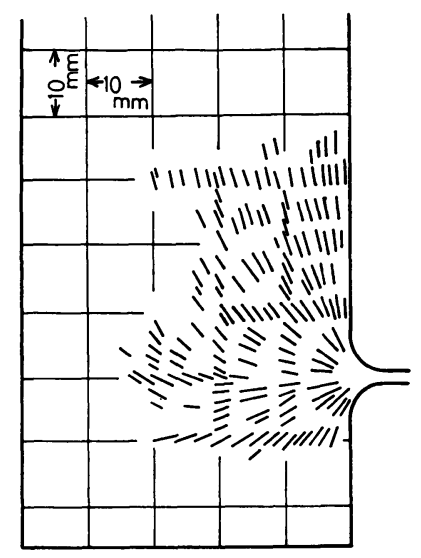

(b)

Fig. 7 Flow and alignment of staples in the tank.

(a) $\nu=108 \times 10^{-6} \mathrm{~m}^{2} / \mathrm{s}, H=50 \mathrm{~mm}, v_{\mathrm{s}}=1.01 \mathrm{~cm} / \mathrm{s}$,

(b) $\nu=30.4 \times 10^{-6} \mathrm{~m}^{2} / \mathrm{s}$, Specimen B, $H=50 \mathrm{~mm}, v_{\mathrm{s}}=2.33 \mathrm{~cm} / \mathrm{s}$.

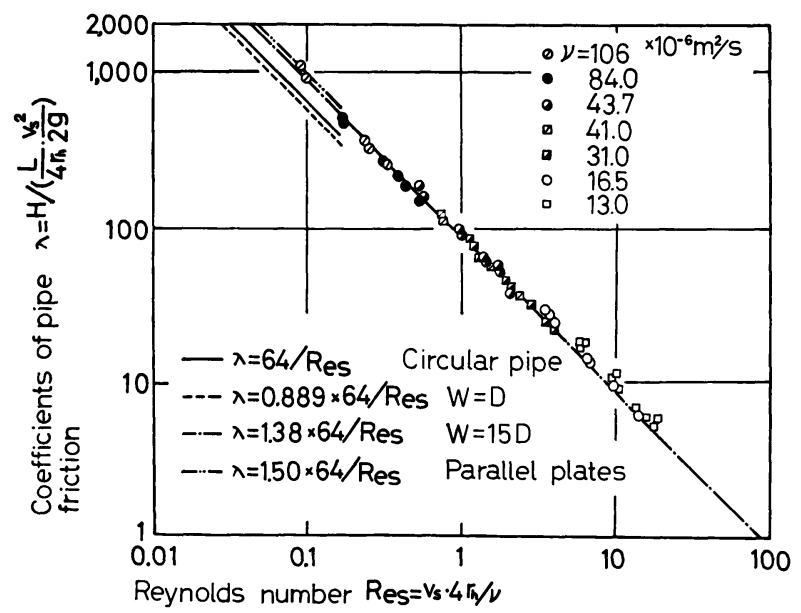

Fig. 8 Coefficients of pipe friction for the rectangular duct.

に示してある. $H=30 \mathrm{~mm}$ の位置まで夜面が降下する と, タンク内の全領域にわたって頭髪は配列する.

実験で得られた短繊維に関するレイノルズ数 $\operatorname{Re}_{\imath}$ は, 理論で仮定した $\operatorname{Re}_{l}<2.72$ を満足している.

\section{4 管路内での短織維の配列}

透過光を用いて管路内での資料の配列状態を写真撮影
した．との代表例を Fig. 10 に示す．流れは写真の左か ら右へ流れている.

これらの写真より管路の位置, 資料のアスペクト比, 速度ならびに作動液の粘度の配列状態におよぼす影響を 見いだした結果, Fig. 11 に示す曲線が得られた.

$X=20 \mathrm{~mm}$ の場合は 409 本, $X=100 \mathrm{~mm}$ の場合は 


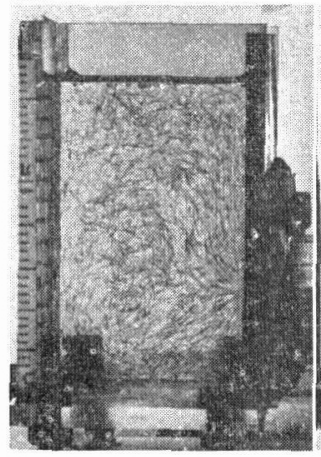

(a)

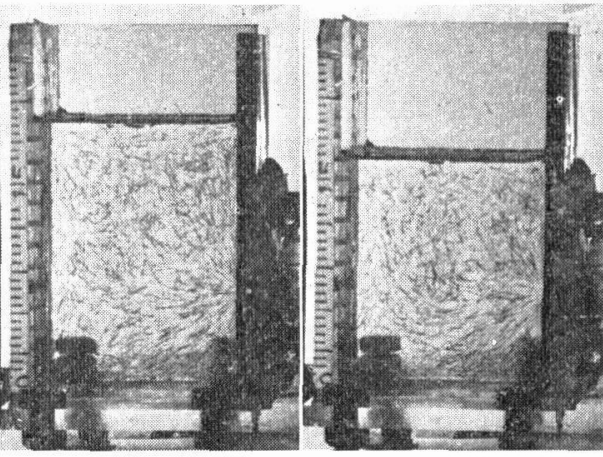

(c)

Fig. 9 Alignment of staples in the tank.

(a) $H=50 \mathrm{~mm}, v_{\mathrm{s}}=2.33 \mathrm{~cm} / \mathrm{s}, \quad$ (b) $H=40 \mathrm{~mm}, v_{\mathrm{s}}=1.85 \mathrm{~cm} / \mathrm{s}, \quad$ (c) $H=30 \mathrm{~mm}, v_{\mathrm{s}}=1.38 \mathrm{~cm} / \mathrm{s}$, $\nu=30.4 \times 10^{-6} \mathrm{~m}^{2} / \mathrm{s}$, Specimen B.

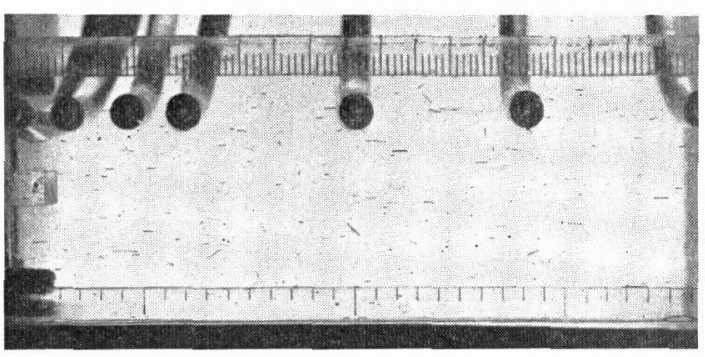

Fig. 10 Alignment of staples in the duct. $\nu=40.8 \times 10^{-6} \mathrm{~m}^{2} / \mathrm{s}$, Specimen A, $H=50 \mathrm{~mm}, v_{\mathrm{s}}=$ $2.67 \mathrm{~cm} / \mathrm{s}$.

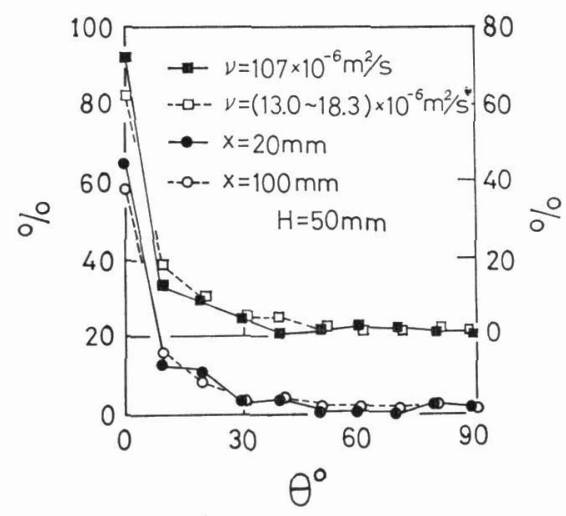

Fig. 11 Staple orientation.

663 本の資料の配列状態を 10 度刻みに読み取って得ら れた．頭髮は管路入口で十分軸方向に配列して打り，下 流に流れるにしたがって配列が崩れる．これは管壁と頭
髪とのまさつが影響していると考えられる．この結果よ り，管路出口での配列状態をよくするには，管路の長さ はできるだけ短くすればよいことがわかる.

管路内での頭髪の配列は，アスペクト比の大きいほう が悪くなった。このことは，一見理論で述べた配列にお よぼすアスペクト比の影響と矛盾するかのごとく思われ るが, 理論と実験が示すと括り, 配列時間は非常に短く, タンク内で短繊維は完全配列をすませている．配列を完 了した短䋐維は管路入口に到達したのち，管壁とのまさ つによってその配列が悪化する，アスペクト比の大きい 資料 Bは，その平均長さが管路の厚さよりも大きいの で，資料Aに比して管路とのまさつの影響をより強く受 けたと考えられる。

管路内の速度 $v_{\mathrm{s}}=6.0 \sim 7.9 \mathrm{~cm} / \mathrm{s}$ の場合は 338 本, $v_{\mathrm{s}}=2.0 \sim 3.9 \mathrm{~cm} / \mathrm{s}$ の場合は 458 本の頭髮から配列を評 価した．その結果管路内の流速が早いとき配列が良好で あることがわかった．これは，流速の増大につれて，管 路内ならびにタンク内の速度こう配が増加することに起 因すると考壳られる。

粘度の影響は，Fig. 11 に示すよらに，粘度の増大に つれて配列はよくなる。そして配列角度が 10 度以内に あるものが全体の頭髪数の 70 パーセントに達する. こ の值は射出生成された GFRP のときの配列状態7)より も数倍良好である. ここで Fig. 11 に示された曲線は, $\nu=107 \times 10^{-6} \mathrm{~m}^{2} / \mathrm{s}$ の歹のは 195 本, $\nu=(13.0 \sim 18.3) \times$ $10^{-6} \mathrm{~m}^{2} / \mathrm{s}$ のものは 588 本の資料から得られた. 


\section{5. 結 論}

流体工学的見地から, 流動している液体中の短繊維の 運動を調べた結果，以下に示す結論が得られた。

1）速度こう配を有する流体中の短㵶維の運動は式(11) で与えられる。

2) 式(11)で求められる配列時間は非常に小さく，短緎 維はタンク内で配列を完了する，そのときの配列時間 は, 速度こう配, 短繊維の長さ, 流体密度, 流体の粘度 の増大ならびに短緎維の直径, 短緘維の密度の減少につ れて減少する。

3）管路出口で良好な配列を得るには，配列状態を悪 化させる管路は短いほどよい。

4）管路内の流速が増大すれば，タンク内および管路 内の速度こう配が増加するので, 短緘維の配列は良好と なる.

5）粘度の増加とともに管路内の配列は良好となり，
配列角度が 10 度以内にあるものが，全体の短繊維の 70 パーセントを占める.

\section{参考文 献}

1) C.A. Calow \& R.J. Wakelin :J. Inst. Metals, 96, 5 (1968), 147-154.

2) 加藤健三, 斎藤好弘, 中西康裕 : 昭和 50 年度塑 性加工講演会 (1975), 245-248.

3) C.W. Oseen : Ark. f. Mat. Astr. og. Fys., 6, 29 (1910).

4) J. Boussinesq : J. Mathe., Pures et Appliquees, 7 (1868), 377-424.

5) G.G. Stokes : Trans. Camb. Phil. Soc., 9, 8 (1845), 8.

6) 寺沢寛一 : 自然科学者のための数学概論, 応用編, 岩波書店 (1963), p. 434.

7）鈴木 恵, 宗宮 詮, 前田正彦, 片桐寛機：高分 子化学, 28, 309 (1971), 1-7. 